\title{
TYPOLOGY OF ACTUALIZATION OF NOUN DENOTATS IN SPONTANEOUS FIGURATIVE COMPARISONS (on the example of femme and homme nouns)
}

\author{
Mustaeva Guldora Salakhiddinovna, \\ Independent researcher at the Department of \\ French Language and Literature \\ of Samarkand State Institute of Foreign Languages; \\ Samarkand State Institute of Foreign Languages \\ 140104, Samarkand, Bustonsaroy str., 93, Uzbekistan \\ e-mail: home.31@mail.ru
}

http://dx.doi.org/10.26739/2573-5616-2018-3-1-12

\begin{abstract}
In this article, the typology of actualization of denotats of femme and homme nouns in spontaneous figurative comparisons is considered. All kinds of semantic opposition, which underlies the choice and actualization of each denotat of the considered nouns in the position of the core comparison, are determined and systematized. The ways of forming additional new semes are shown as the result of actualization of each semantic opposition in the combinatorial content of spontaneous comparisons with femme and homme components.
\end{abstract}

Key words: image comparison, spontaneous comparison, theme comparison, core comparison, denotat, semantic opposition.

At the present stage of the development of linguistics, interest in the semantic interpretation of figurative means is constantly increasing. In describing the patterns of formation and perception of images, it is emphasized the need to take into account the characteristics of the speakers of the language and the units of their thinking. The attempts to explore figurative means in the mirror of units of thinking are just beginning. The main attention in the works of the French semasiologists, is drawn to the definition of the semantic mechanism of metaphor $[1 ; 6]$. Although the semantic mechanism of comparison has many common with a metaphor, the ways and patterns of formation of their images differ completely from each other and each has its own semantic features. If we take into account the relation of figurative comparisons to the levels of language and speech, then these semantic features will be even deeper. The images 
in stable comparisons or comparative phraseological units fixed in lexicographical sources are historically formed and transmitted from generation to generation. Figurative comparisons formed in the speech situation are not fixed in the dictionaries of the French language, but they are widely used in the speech of French speakers. In such figurative comparisons, the formation of images occurs in the speech environment, and semantic and cognitive factors that influence the formation and selective use of the image have not been studied yet. Studying their semantic identity, learning semantic processes among their components, and disclosing the cognitive laws underlying their images are among the topical issues of modern semiology and cognitology. The questions of study of semantic and cognitive factors that influence the selection of figurative comparisons formed in the speech environment, and on this basis, of their classification, are one of the topical issues of contemporary linguistics.

Numerous scientific articles, monographs, dissertations are devoted to the study of figurative comparisons [2; 3; 7]. However, in all current scientific research, the attention of researchers was drawn to the study of stable comparisons related to the dictionary fund of the language $[9 ; 10 ; 11]$. Stable comparisons or comparative phraseological units served as topics for the study of various disciplines, such as phraseology, lexicology and lexicography, stylistics and literary texts. In recent times, some aspects of comparison structures have been developed for the study of psycholinguistics and semantic syntax. For example, there are a number of theses that described the comparison as comparative functional semantic categories [8], characterized the formation of figurative comparisons on the basis of presuppositions [5], identified the contextual relationship of figurative comparisons [4]. Critical analysis of these studies has allowed illustrating the existence of unresolved issues related to the study of figurative comparisons from the point of view of contemporary trends in linguistics. These include: a) interpretation of spontaneous comparisons as one of the ways of conceptualization of knowledge about the universe; b) the description of spontaneous comparisons as semantic model reflecting the semes of their components and combinatorial-semantic relationships between their components. In our article we analyze semantic factors that influence the formation of spontaneous comparisons formed in the speech environment.

Relationship of the form of comparison with the thinking categories reflect the semantic model of comparison, i.e. the actualization of the meaning of comparison in the text. In this case, the focus should be on how to look at the possibility of formulating the meaning of comparison in a composite text. In the process of observing the content of figurative comparisons, the researcher has at least two problems: the first one is the 
problem of re-understanding the semantic paradigm of the same words as a unity of dictionary by studying the real "life" of the words used in the components of the comparison, the second problem is to determine the relationship between the semantics of asingle word and the semantics of the whole comparison. The analysis of meaningful relationships between words used in place of components of figurative comparisons is one of the issues directly related to the theory of semantic complexion, because the combination of meaningful words in comparative structures occurs with specific processes of combining meanings, with combinatorial increase of meanings. In such cases, the point of observation is not only lexicalsemantic versions of the words used in the place of similar objects, but also categorical semes and semantic components of these meanings. Let's compare the following comparative structures: 1. Il y avait eu de braves jeunes gens, honnétes, protestants, un peu ridicules, - Scandinaves ou Suisses, - qui avaient réclamé l'égalité dans la vertu; les hommes arrivent au marriage, vierges comme les femmes [28, 397]. 2. Ils y ont laissé aussi un colonel de la ligne, un grand blond, la peau blanche comme une femme, et des bottes jaunes toutes neuves [17, 159]. 3. Ma belle-mére attandait, le visage souriant, les remerciements que je me suis finalement décidé á lui addresser, mais je crois surtout qu'elle a été sensible, comme ma femme, á mon hésitation et á l'ennui qu'elle indiquait [21, 42]. 4. ...madame Vermont m'aimait beaucoup, elle me (Marie) traitait plutét comme une compagne que comme une femme de chambre [22, 163].

The word femme, as a unit dictionary, combines three lexical-semantic variants in its semantic structure. Each lexical-semantic variant participates in creating comparative structures on its own sign. In the first and second examples, the word femme expresses a broad concept and indicates the referent as "female sex, woman", in the third case it represents a relatively narrow concept "wife" and in the fourth case, the word femme indicates the referent completely different as" made, housekeeper". Thus, the core of the comparison has been replaced by three types of referent of femme. Let's draw attention to the semantic factors affecting the selection of each referent as a core of the comparison: 1. Mévil entrait, précédé d'un boy annamite de douze ans qui marchait en se déhanchant comme une femme $[18,11]$. 2. Elle (Agathe) devint, á quarante-sept ans, comme une femme de soixante et dix ans $[12,442]$. 3. Il dit que Rob-Sen était léche, qu'il craignait la guerre comme une femme [29, 70]. 4. Le succés, comme une femme, a ses caprices et son mystére [Bordeaux, Croisée, 226]. 5. Les planétes, comme les femmes, ont besoin d'un époux, ... [26,102].

In the above figurative comparisons, some of the semantic components of the theme and of the core of comparison collide with each other in 
different ways, creates the different types of contexts. In examples 1-3, the composition of categorical semes of the theme and of the core of comparison corresponds to one another, both in the context of comparison and beyond. However, the sema "elder" (in examples 1 and 2), the seme "female" (in 3 example) and the seme "anthroponym" (in 4 and 5 examples), contained within the comparison core, become the main subject only as a result of establishing comparative-semantic relations with the composition of the semes of the nouns in the position of the theme of comparison. As a result of the establishment of semantic relations between the comparison theme and the comparison core, additional semes appeared in the semantic structure of the comparison theme: not a child, but a woman ( 1 case), not forty-seven, but seventy year old woman (2 example), not a male, woman ( 3 case), not lifeless, live (in 4 and 5 examples).

The possibility of using of a hyperon in the position of the comparison is very large. The noun homme may represent in place of comparison core at least four types of denotats. These are:

1. Homme - human: ...les bétes se parlaient comme des humains [27, 101]. ...la nature travaille absolument comme l'homme, son ouvrier du reste $[15,40]$. Elles (les idées) vivent; elles combattent; elles agonisent comme les hommes $[19,236]$.... les choses, comme les hommes, se sentaient prises de sommeil $[25,73]$.

2. Homme - male (man): Elle (Lorchen) lui (á Christophe) donna une poignée de main vigoureuse, comme un homme [28, 267]....il (bébé) leva la téte, ... prit son assiette é deux mains comme un homme $[20,56]$....les enfants domptés pour se satisfaire, comme les hommes, des repas á heures fixes $[14,119]$.

3. Homme - husband: J'y (Mme Estiévou) étais devenue dure comme mon homme lui-méme [24, 174].

4. Homme - insider: il (officier) descendit de cheval, comme ses hommes $[16,274]$. Les jeunes officiers s'amusaient parfois á parler comme leurs hommes:... [23, 22].

In these contexts, the volume of the meaning of the noun homme, denoting this or that denotat, is not the same, respectively: hyperonym, hyponym, individualized face and persons of a particular social group. The actualization of these meanings depends, in most cases, on the kinds of semantic oppositions formed between the components of the figurative comparison: in the first context of comparison - semes anthroponym, consciousness, ability to perform the action, source of life, appearance; in the second semes gender, age; in the third and fourth - seme social status.

Summary. The words femme and homme, as dictionary unit, combine 3 and 8 lexical-semantic variants according to their semantic structures. Four denotats of the noun homme (human, male (man), husband, insider) 
and three denotats of the noun femme (woman, wife, made (housekeeper)) are widely used in the position of the comparison core for the formation of comparative structures. However, they differ from each other in the frequency of use in the position of the comparison core, in the ability to form comparative structures and the types of semantic oppositions established between the compared nouns in the position of the comparison theme.

The ratio of the lexical meanings of the nouns femme and homme used in the position of the comparison core determines the general and differential semes in their content. These semes are the components of the meaning of these nouns. When they do not have special expression tools in the noun structure, they play an important role in the shaping of the image in the comparison structure. On the basis of contrasting these semes, a certain image in spontaneous comparisons is actualized. For the actualization of three types of denotats within the femme noun, seven types of semantic opposition are required, and for the actualization of four types of denotats of the noun homme, 12 kinds of semantic opposition are required. Moreover, additional new semes formed as a result of actualization of each semantic opposition manifest themselves differentially in the combinatorial content of spontaneous comparisons with the femme and homme components. The study of the ways of forming new additional semes in the meaning of comparison allows, firstly, to determine the semantic mechanism of the formation of spontaneous figurative comparisons, secondly, to discover new semes in anthroponyms of different categories, and third, to establish the communicative significance of the comparative content.

\section{References}

1. Bouverot D. Comparaison et metaphore // Le Frangais moderne, 1969. № 2, 3, 4.

2. Cazelles, N. Les comparaisons du français. Coll. Le français retrouvé. Paris: Belin, 1996. $333 \mathrm{p}$.

3. Fuchs, Catherine. La comparaison et son expression en français. Paris: Ophrys, 2014. 180 p.

4. Golysheva V.G. Семантическая структура и контекстуальные связи образных сравнений Л., 1984. 19c.

5. Исмаилов С.И. Семантическая характеристика образных сравнений во французском языке (на материале художественных произведений X1X-XX вв.). Ленинград, 1980. 23c.

6. Le Guern M. Sémantique de la métaphore et de la métonymie. Paris: Larousse, 1972.125 p.

7. Мартынова А.А. Названия животных в составе УС (на материале французского языка) // Современный французский язык в его динамическом аспекте. Сборник научных трудов / МГПИ им. Ленина. М., 1987. С.94-105.

8. Михалев, А. Б. Функционально-семантическая категория сравнения в современном французском языке: автореф. дис. ... канд. филол. наук: 10.02.05. М., 1982. 24 с. 
9. Moline, E. Belle comme un cœur/Belle comme sa sœur. Pour une description unifiée des comparatives en comme // L'information grammaticale,111. Louvain, Peeters, 2006. p. 14-20.

10. Назарян А.Г. Устойчивые сравнения во французском языке: Справочник. М., Изд. «Высшая школа», 1992.

11. Vigh, A. Comparaison et similitude // In Le français moderne, 43ème année, $N^{\circ} 3.1975$.

Belles-lettres

12. Balzac, Honoré de. Les célibataires. t.1. Paris: Paul Ollendorff, 1901. 447 p.

13. Bordeaux, Henry. La croisée des chemins. Paris: Plon-Nourrit et cie, s.d. 367 p.

14. Cesbron, Gilbert. Notre prison est un royaum. Paris: Albert Laffont, 1952. 245p.

15. Coulevain, Pierre de. Au coeur de la vie. Paris: Alphonse Lemerre,1894.302 p.

16. Dargène, Jean. Pour un baiser. Paris: G.Havard fils, 1897. 357 p.

17. Daudet, Alphonse. Contes et nouvelles choisies. M.: Éd. en langues étrangères, 1955. 692 p.

18. Farrère, Claude. Les civilisés, 66 éd. Paris: Paul Ollendorff, s.d. 319 p.

19. Gide, André. Les faux Monnayeurs. Paris: Gallimard, 1925. 495 p.

20. Gréville, Henry. L'amie, 20 éd. Paris: Plon-Nourrit et cie, s.d. 295 p.

21. Hourgon, Jean. Je reviendrai à Kandara. Paris: Éd. Mondiales, 1955. 192 p.

22. Kock, Charles Paul de. Les enfants du boulevard. Paris: Ferd. Sartorius, 1864. 275 p.

23. Lanoux, Armand. Le commandant Watrin. M.: Éd. en langues étrangères, 1962. 383 p.

24. Lesueur, Daniel. L’or sanglant. Paris: Alphonse Lemerre, 1900. 430 p.

25. Loti, Pierre. Pages choisies. Paris: Hachette, 1952. 94 p.

26. Maupassant, Guy de. Sur l'eau. Paris: Paul Ollendorff, 1904. 240 p.

27. Plume, Christian. Les contes de mon mas. Paris; France-Empire, 1975. 220 p.

28. Rolland, Romain. Jean-Christophe, t. 1,2. M.: Éd. en langues étrangères, 1957.

29. Rosny, J.-H. L’impérieuse bonté. Paris: Plon-Nourri et cie, s.d. 371 p. 